\title{
Evaluation of Quality in the Adhesion of Glued Laminated Timber (Glulam) of Paricá and Lyptus Wood Species
}

\author{
Diego Henrique de Almeida ${ }^{1}$, Raquel Schmitt Cavalheiro ${ }^{2}$, Laurenn Borges de Macêdo ${ }^{2}$, \\ Carlito Calil Neto ${ }^{3}$, André Luis Christoforo ${ }^{4, *}$, Carlito Calil Junior ${ }^{5}$, Francisco Antonio Rocco Lahr ${ }^{5}$ \\ ${ }^{1}$ Pontifical Catholic University of Minas Gerais (PUC Minas), Department of Civil Engineering, Poços de Caldas Campus, Poços de Caldas, \\ 37701-355, Brazil \\ ${ }^{2}$ Department of Materials Engineering (SMM), Engineering School of São Carlos (EESC/USP), São Carlos, 13566-590, Brazil \\ ${ }^{3}$ Wood and Timber Structures Laboratory (LaMEM), Engineering School of São Carlos (EESC), São Carlos, 13566-590, Brazil \\ ${ }^{4}$ Centre for Innovation and Technology in Composites (CITeC), Department of Civil Engineering (DECiv), Federal University of São \\ Carlos (UFSCar), São Carlos, 13565-905, Brazil \\ ${ }^{5}$ Department of Structures Engineering (SET), Engineering School of São Carlos (EESC/USP), São Carlos, 13566-590, Brazil
}

\begin{abstract}
This research aims to study the shear strength of species-adhesive-moisture-waterproofing combinations and delamination of Glued Laminated Timber (Glulam) made with Paricá (Schizolobium amazonicum Herb) and Lyptus Wood species, using two different adhesives, the bicomponent resorcinol-formaldehyde based adhesive (CASCOPHEN RS-216-M) with catalyst FM-60-M and the bicomponent melamine-urea based adhesive with catalyst AkzoNobel MUF 1242/2542, both in a proportion of 100 parts/adhesive mass and 20 parts/catalyst mass and waterproofed by the commercial product ProtectGuard. Shear strength tests in adhesion line were performed according to North American Standard AITC 190: 2007 and delamination tests were carried out obeying Canadian Code CSA 0177: 2006. The results show that average values of great shear strength were obtained in tests on the glue line of the specimens treated with the waterproofer, however, within them, the timber was dry. Lyptus Glulam beams did not present a performance in delamination that was compatible to external applications, but Paricá beams are fit to this use, once they are previously treated.
\end{abstract}

Keywords Glulam, Quality in the adhesion, Shear strength, Delamination

\section{Introduction}

Wood is one of the oldest materials used by humans in several applications. One of the most important has been the assembling of structures for housing, and also to overcome natural obstacles. However, with the discovery of steel and concrete, wood lost its main role in construction.

Nowadays, there is a search for renewable resources, looking for lower environmental damage in the use of natural resources in human activities, and the timber from reforestation is a promising raw material, concerning sustainability, for all the engineered timber products.

Many considerations can employed concerning the growing of timber products in construction, including: forestry management, sawmill and industrial benefiting, fast light-weight timber structures industrialization, reforestation of exotic and native species, use of higher quality

* Corresponding author:

alchristoforo@yahoo.com.br (André Luis Christoforo)

Published online at http://journal.sapub.org/ijme

Copyright (C) 2014 Scientific \& Academic Publishing. All Rights Reserved preservatives, among others $[1,2]$

Of the several kinds of engineered timber products, one can cite, the Glued Laminated Timber (Glulam) (Figure 1), which represents a material built by gluing wood boards to one another in such a way that the grains remain parallel [3].

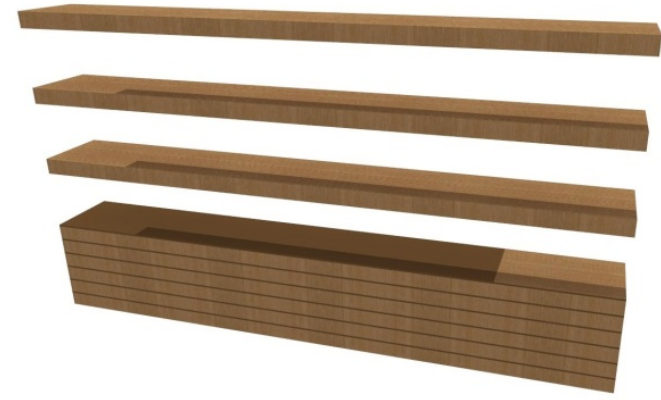

Figure 1. Scheme of the assemblage of a structural beam of Glulam

The Glulam can be applied in several structural assemblages as catwalks, stairs, bridges, covers and roofs. It can also make the preparation of long path beams possible in large timber structures [4]. In the production of Glulam, the choice of the adhesive for structural members strongly 
depends upon the environment and the conditions of exposition during its use [5].

In the preparation of Glulam structures, it is indispensable to have standards available to define the guidelines for building such pieces and the structure dimensions and parameters. Thus, the research on different species, adhesives and treatments is necessary to control the production quality of Glulam by the industries for the safe and secure application of the final product [6].

Another feature of Glulam is the integrity of the glue line, once it guarantees the union of the boards and the integrity of the entire piece. As wood is a hygroscopic material, retaining environmental water [7], the glue line can be affected, reducing the mechanical resistance of the piece, and it can lead to the delamination of the structure and its failure.

It is possible to glue practically all wood species. However, some species have physical and chemical characteristics which require the use of special glues or modification of glues, normally commercialized for use on wood. Usually, the most appropriate species for the production of Glulam are the conifers, due to their great porosity and anchoring of adhesives, however, some hardwoods of reforestation are also indicated in the production of Glulam, such as Lyptus and Paricá.

Lyptus is a widely produced species in commercial plantations in Brazil, it is being considered a kind of hardwood of great natural durability. Unlike Lyptus, Paricá (Schizolobium amazonicum Herb) (although it is a species of Amazonian origin that has been cultivated on a large scale in the country, because of its fast growth) does not have good natural durability when exposed to a high humidity environment and high temperature, which is a very characteristic climate of Brazil $[8,9,10,11]$. Therefore, when wood is used in this kind of environment, a special treatment is required, in other words, the wood must be treated in a preservative impregnation process against the biological demand.

The Glulam is an engineered product that can only have its quality tested in laboratory conditions; however, quality control is necessary in its production to ensure that their properties comply with the requirements specified for the product, according to current standards. Delamination is the ungluing of the lamellae, laterally glued or glued face-to-face; the delamination test shows the behavior of the adhesive with the species of wood used. The same occurs in the shear strength test - some force is perpendicularly applied to the length of the longitudinal axis, in response to the shear strength, the material develops a reaction on the glue line, called shear strength. Thus, these data of tests are sufficient to draw conclusions about the quality of the production process and the combination of species with adhesive-treatment-preservative.

For this reason, this work aims to investigate the influence of a commercial waterproofing agent in shear strength test on the glue line and the propensity to delamination of test specimens made of beams of Glulam built of the Brazilian reforesting trees Paricá and Lyptus.

\section{Material and Methods}

The experimental tests was developed in the Wood and Timber Structures Laboratory (LaMEM), of the Department of Structural Engineering (SET), of the School of Engineering of São Carlos (EESC), of the University of São Paulo (USP) according to the specifications defined by ABNT NBR 7190:1997 [13], AITC 190:2007 [14] and CSA 0177:2006 [15] Codes.

For the tests, four beams of Glulam were made, with three blades each, after these were visually classified, followed by transversal vibration. Two of the beams were prepared with Paricá and two with Lyptus. For both wood species, one beam was prepared with a resorcinol-formaldehyde (CASCOPHEN RS-216-M) as adhesive, and FM-60-M catalyst and the other beam was glued with a melamine-urea adhesive and Akzo Nobel MUF 1242/2542 catalyst; the same procedure is used in beams of Lyptus. The Cascophen adhesive were made with catalyst FM-60-M and the bicomponent melamine-urea based adhesive with catalyst AkzoNobel MUF 1242/2542, both in a proportion of 100 parts/adhesive mass and 20 parts/catalyst mass and waterproofed by the commercial product ProtectGuard.

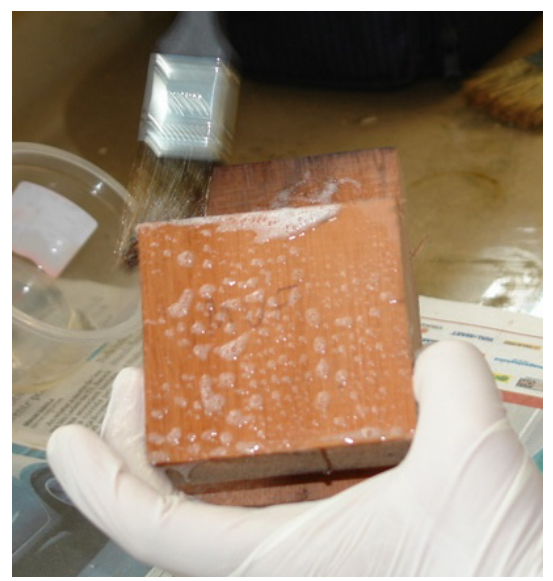

Figure 2. Specimen being coated with the ProtectGuard waterproofing agent

For each beam, 9 test specimens were made for the shear test in the glue line, according to the AITC 190:2007 [14] standard. Three of these specimens were treated with the waterproofing agent ProtectGuard (Figure 2), and immersed in water for $48 \mathrm{~h}$ (Figure 3). The other specimens were not treated with the waterproofing agent and also immersed in water for $48 \mathrm{~h}$ (Figure 4), and other three were kept at room humidity (Figure 5).

All test specimens had their respective shear strength areas measured with a $0.01 \mathrm{~mm}$ precision digital caliper and then tests were carried out in the AMSLER universal testing machine with a $100 \mathrm{kN}$ load capacity.

The shear strength the glue line $\left(f_{v}\right)$ is defined as the quotient between the maximum shearing charge applied $\left(\mathrm{F}_{\mathrm{v}}\right)$ 
and the area resistant to the shearing in the glue line $\left(\mathrm{A}_{\mathrm{v}}\right)$ (Equation 1).

$$
\mathrm{f}_{\mathrm{v}}=\frac{\mathrm{F}_{\mathrm{v}}}{\mathrm{A}_{\mathrm{v}}}
$$

For delamination tests, 9 test samples were made of beams of Glulam of Lyptus and 9 made of Paricá (Figure 6) glued with a resorcinol-formaldehyde adhesive. Nine test samples of beams of Glulam of Lyptus and 9 made of Paricá glued with melamine-urea adhesive. The tests were carried out obeying Canadian Code CSA 0177: 2006 [14].

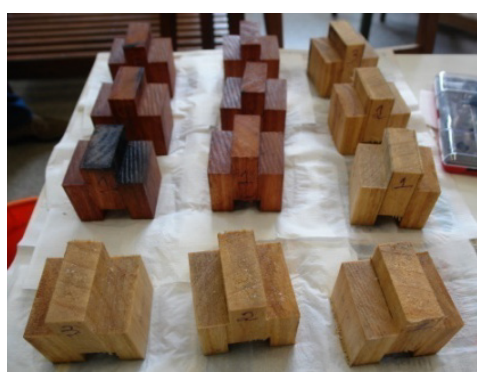

(a)

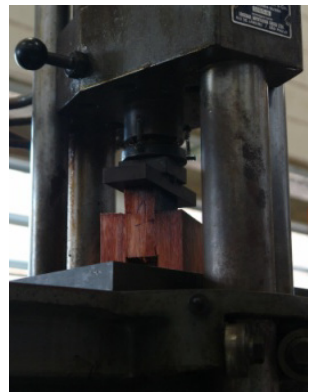

(b)
Figure 3. (a) Specimens coated with the waterproofing ProtectGuard agent after immersion in water for 48 hours; (b) specimen of Lyptus with MUF waterproofed adhesive in test

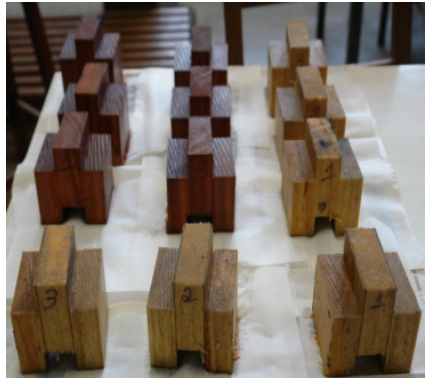

(a)

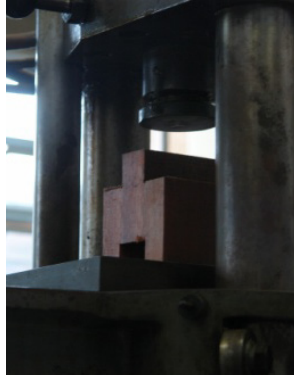

(b)
Figure 4. (a) Specimens without waterproof coating after immersion in water for 48 hours; (b) specimen of Lyptus with CASCOPHEN adhesive in test

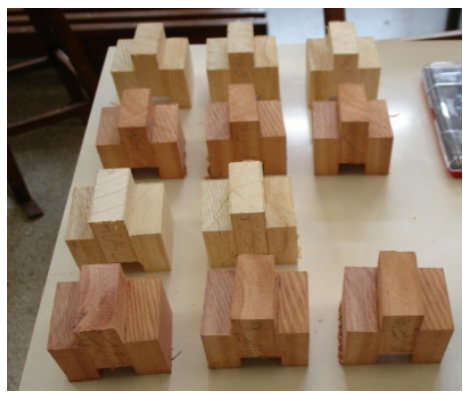

(a)

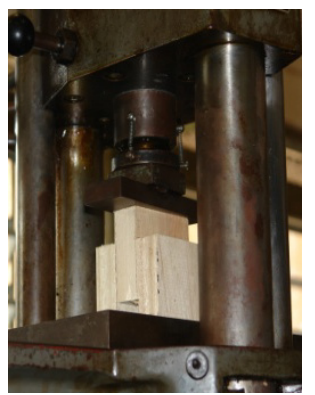

(b)
Figure 5. (a) Specimens without waterproofing coating, kept at ambient humidity; (b) specimen of Paricá with dry MUF adhesive in test

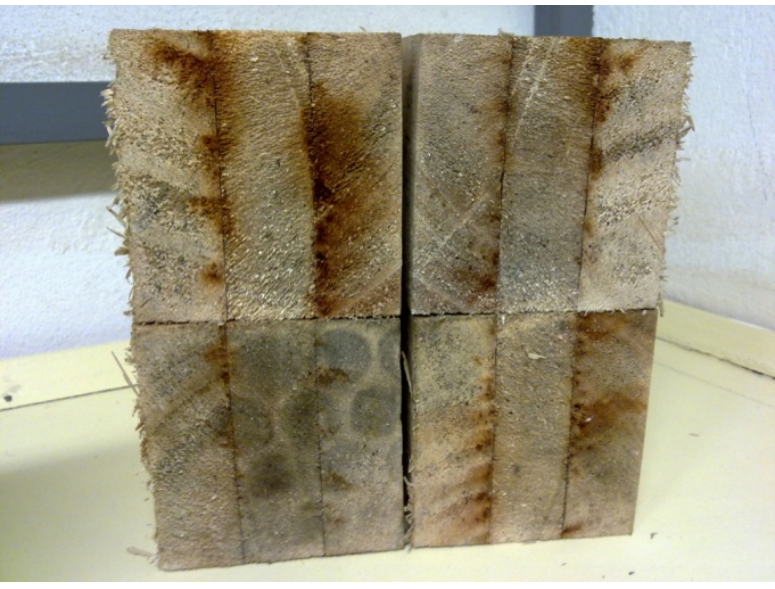

Figure 6. Structural Paricá specimen for delamination tests

\section{Results and Discussions}

Table 1 shows average values and the variation coefficient of shear resistance in the glue line of dry, humid and waterproofed with three test specimens each.

Table 1. Average glue line shear strength values (in $\mathrm{MPa}$ ) and variation coefficient (in percentage) for the different combinations of wood-adhesive-moisture-waterproofing agent $(\mathrm{MPa})$

\begin{tabular}{c|cc|cc}
\hline Species & \multicolumn{2}{|c|}{ Lyptus } & \multicolumn{2}{c}{ Paricá } \\
\hline Treatment & MUF & CASCOPHEN & MUF & CASCOPHEN \\
\hline \multirow{2}{*}{ Dry } & 9,50 & 7,75 & 6,20 & 6,70 \\
& $(16 \%)$ & $(18 \%)$ & $(6 \%)$ & $(12 \%)$ \\
Humid & 7,90 & 6,60 & 5,50 & 4,85 \\
& $(12 \%)$ & $(21 \%)$ & $(15 \%)$ & $(19 \%)$ \\
Waterproofed & 7,70 & 6,25 & 4,40 & 4,60 \\
& $(8 \%)$ & $(11 \%)$ & $(16 \%)$ & $(13 \%)$ \\
\hline
\end{tabular}

The highest average values for strength in the glue line had been obtained by the specimens glued with MUF, when compared with those glued with CASCOPHEN. However the values were different when the wood is Paricá, probably due to the physical and chemical properties of the wood.

Dry specimens presented higher strength values when compared to the wet ones in the species-adhesive -waterproofing agent. This is similar to previously reported results $[6,15]$, in which the authors attributed the difference to the decrease in the strength of the wood when its water content increases.

All the specimens presented rupture in the wood. However, despite the waterproofed test specimens show average shear strength values close to those determined to non-waterproofed test specimens, revealing that the waterproofer does not interfere with the adhesion, the dry inside part of wood of the waterproofed test specimens confirms the efficiency of the waterproofing process (Figure 7). 


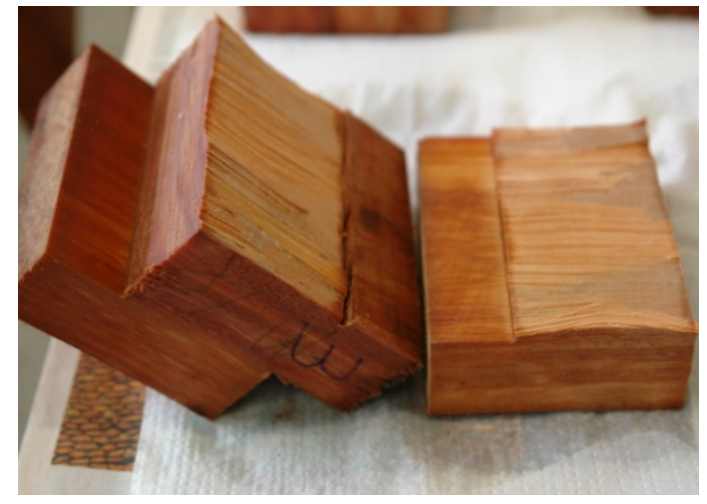

Figure 7. Waterproofed Lyptus specimen at the end of the shear test, showing that the wood inside is still dry, even after $48 \mathrm{~h}$ immersion in water

The Table 2 shows the results of Lyptus delamination, once the 9 test samples made of Paricá wood and melamne-urea did not suffered delamination. Glulam made with resorcinol-formal adhesive did not suffered delaination [15].

Table 2. Average values of delaminations tests and variation coefficient (in percentage) for different Lyptus with waterproofing agent

\begin{tabular}{cc}
\hline Lyptus & Delamination \\
\hline Resorcinol-formol & $3,86 \mathrm{~cm} \mathrm{(13 \% )}$ \\
Melamine-urea & $2,30 \mathrm{~cm}(18 \%)$ \\
\hline
\end{tabular}

The results show that Glulam beams made of Lyptus wood associated with the mentioned adhesives cannot be used in outdoor environments because of the high percentage of delamination (exceeding 1\%). However, despite the produced Glulam beams made of Paricá wood had the best performance in delamination than any other wood, this species is very susceptible to attack by wood decay agents. As wood treatment does not interfere in the bonding process [6], the Paricá wood must always be treated before using in Glulam.

\section{Conclusions}

The waterproofing agent used in this research did not interfere with the strength in the glue line, during the shear tests. However, when it is used, the wood is still dry inside the sample, what reduces the risks of attacks of wood decay organisms that degrade the wood, during its application.

Beams produced with Lyptus wood and resorcinol-formaldehyde and melamine-urea adhesives were qualified for indoor use, because of their high percentage of delamination (exceeding 1\%).

Paricá is a great species of wood for the production of Glulam, however it should always be treated with a preservative agent, and should be used for outdoor environment.

\section{ACKNOWLEDGMENTS}

The authors would like to acknowledge the responsible for the Wood and Timber Structures Laboratory (LaMEM), of the Department of Structural Engineering (SET), of the School of Engineering of São Carlos (EESC), of the University of São Paulo (USP), for the availability of resources and materials during the realization of this work. Thanks also to the Brazilian agencies CAPES and CNPq for their partnerships and research grants.

\section{REFERENCES}

[1] Bertolini, M. S. Emprego de resíduos de Pinus sp tratado com preservante $\mathrm{CCB}$ na produção de chapas de partículas homogêneas utilizando resina poliuretana à base de mamona. Dissertação de Mestrado. Interunidades em Ciência e Engenharia de Materiais, Universidade de São Paulo, São Carlos, 2011.

[2] Morales, E. A. M. Determinação do módulo de elasticidade da madeira: proposta para a simplificação de procedimentos metodológicos. Dissertação de Mestrado. Interunidades em Ciência e Engenharia de Materiais, Universidade de São Paulo, São Carlos, 2005.

[3] Miotto, J. L. Estruturas mistas de madeira-concreto: avaliação das vigas de madeira laminada colada reforçadas com fibras de vidro. Tese de Doutorado. Departamento de Engenharia de Estruturas, Escola de Engenharia de São Carlos, Universidade de São Paulo, São Carlos, 2009.

[4] Aprilanti, M. D. Influência de um corte na borda tracionada de uma viga maciça simulando uma emenda de topo na lâmina inferior de vigas laminadas coladas. Dissertação de Mestrado. Escola Superior de Agricultura "Luiz de Queiróz", Universidade de São Paulo, Piracicaba, 2010.

[5] Pizzi, A. Advanced wood adhesives technology. Marcel Dekker, New York, 1994.

[6] Calil Neto, C. Madeira laminada colada (MLC): controle de qualidade em combinações espécie-adesivo-tratamento preservativo. Dissertação de Mestrado. Interunidades em Ciência e Engenharia de Materiais, Universidade de São Paulo, São Carlos, 2011.

[7] Calil Junior, C.; Lahr, F. A. R; Dias, A. A. Dimensionamento de elementos estruturais de madeira. Manole, Barueri, 2003.

[8] Ferro, F. S. Painéis OSB com madeira Schizolobium amazonicum e resina poliuretana à base de óleo de mamona. Dissertação de Mestrado. Escola de Engenharia de São Carlos, Universidade de São Paulo, São Carlos, 2013.

[9] Almeida, D. H.; Cavalheiro, R. S.; Scaliante, R. M.; Christoforo, A. L.; Calil Junior, C.; Lahr, F. A. R. Full characterization of strength properties of Schizolobium amazonicum Wood for timber structures, International Journal of Engineering \& Technology, v. 13, n.6, p. 97-100, 2013.

[10] Almeida, D. H.; Scaliante, R. M.; Macêdo, L. B.; Macedo, A. N.; Dias, A. A.; Christoforo, A. L.; Calil Junior, C. Caracterização complete da Madeira da espécie amazônica Paricá (Schizolobium amazonicum HERB) em peças de dimensões estruturais, Revista Árvore, v. 37, n.6, p. 1175-1181, 2013. 
[11] Icimoto, F. H.; Ferro, F. S.; Varanda, L. D.; Souza, A. M.; Almeida, D. H.; Christoforo, A. L.; LAHR, F. A. R.. Physical and mechanical properties of Paricá wood species treated with CCB preservative, International Journal of Materials Engineering, v. 3, p. 82-86, 2013.

[12] Associação Brasileira de Normas Técnicas. NBR 7190: Projeto de estruturas de madeira. Rio de Janeiro, 1997.

[13] AITC 190:2007. Structural glued laminated timber. Colorado, 2007.
[14] CSA 0177:2006. Qualification code for manufacturers of structural glued-laminated timber. Edmonton, 2006.

[15] Almeida, D. H.; Scaliante, R. M.; Macêdo, L. B.; Macedo, A. N.; Calil Junior, C. Madeira laminada colada (MLC) da espécie Paricá, Madeira: Arquitetura e engenharia, v. 12, p. 71-82, 2011. 